\title{
Protective effects of spironolactone against hepatic ischemia/reperfusion injury in rats
}

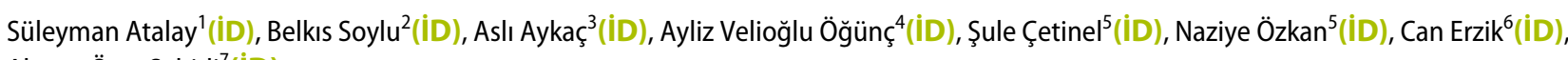 \\ Ahmet Özer Şehirlit, (ID)!' \\ ${ }^{1}$ Department of General Surgery, Haydarpasa Numune Training and Research Hospital, İstanbul, Turkey \\ 2 Department of Pharmacology, Marmara University School of Pharmacy, Istanbul, Turkey \\ ${ }^{3}$ Department of Biophysics, Near East University School of Medicine, Nicosia, Turkish Republic of Northern Cyprus \\ ${ }^{4}$ Department of Biochemistry, Marmara University Vocational School of Health Related Professions, İstanbul, Turkey \\ ${ }^{5}$ Department of Histology-Embryology, Marmara University School of Medicine, Istanbul, Turkey \\ ${ }^{6}$ Department of Medical Biology, Marmara University School of Medicine, İstanbul, Turkey \\ ${ }^{7}$ Department of Pharmacology, Near East University School of Dentistry, Nicosia, Turkish Republic of Northern Cyprus
}

\section{ABSTRACT}

Objective: In the present study, it was aimed to study the antioxidant effects of spironolactone (SPL) to determine its possible protective effects in hepatic ischemia reperfusion injury.

Material and Methods: Hepatic artery, portal vein, and bile duct of Wistar albino rats were clamped for 45 minutes under anesthesia to form an ischemia period. Then reperfusion was allowed and the rats were decapitated 60 minutes later. SPL $(20 \mathrm{mg} / \mathrm{kg}, \mathrm{p} . \mathrm{o}$.) or SF was orally administered for 30 minutes before ischemia. Rats in the control arm underwent sham surgery and were administered isotonic saline. Liver function was studied by measuring aspartate aminotransferase (AST), alanine aminotransferase (ALT), tumor necrosis factor-alpha (TNF-a), and interleukin 1beta (IL-1 $\beta$ ) levels. Malondialdehyde (MDA), glutathione (GSH), luminol, and lucigenin levels, myeloperoxidase (MPO) and $\mathrm{Na}^{+}-\mathrm{K}^{+}-\mathrm{ATP}$ ase enzyme activities were analyzed to study tissue injury under light microscope.

Results: While IR increased AST, ALT, TNF- $\alpha$, and IL-1 $\beta$ levels and MDA, luminol, and lusigenin levels and MPO activities, it caused a decrease in GSH levels and $\mathrm{Na}^{+} \mathrm{K}^{+}$-ATPase activity. Spironolactone administration significantly improved these values.

Conclusion: Protective effects of SPL against ischemia/reperfusion injury via various mechanisms suggest that this agent may become a novel treatment agent in clinical practice.

Keywords: Hepatic ischemia reperfusion, spironolactone, malondialdehyde, glutathione, cytokines

Cite this article as: Atalay S, Soylu B, Aykaç $A$, Velioğlu Ögünç A, Çetinel Ş, Özkan N, Erzik C, Şehirli AÖ. Protective effects of spironolactone against hepatic ischemia/reperfusion injury in rats. Turk J Surg 2019; 35 (4): 285-292.

\section{Corresponding Author}

Ahmet Özer Şehirli

E-mail: ahmetozer.sehirli@neu.edu.tr

Received: 25.10 .2018

Accepted: 04.01.2019

Available Online Date: 16.12.2019

O Copyright 2019 by Turkish Surgical Society Available online at www.turkjsurg.com

DOI: $10.5578 /$ turkjsurg.4340

\section{INTRODUCTION}

Ischemia/reperfusion injury takes place in various clinical settings such as hepatic trauma, hemorrhagic shock, resection of large intrahepatic tumors, and liver transplantation (1,2). The pathophysiology of hepatic ischemia reperfusion injury involves many mechanisms. It consists of several major steps including Kuppfer cell activation, formation of reactive oxygen derivatives, cytokine release, activation of polymorphonuclear leukocytes, altered mitochondrial permeability, and activation of endothelial cells and complement systems, among several other cellular and molecular mechanisms $(3,4)$. These events lead to the activation of local and systemic inflammatory responses, causing injury to local organs.

Aldosterone is secreted by zona glomerulosa in the adrenal cortex. Sprinolactone is a specific aldosterone antagonist. It acts by binding to aldosterone receptors, sparing potassium ions while removing sodium and water in distal tubuli. Its impact on renal ischemia/reperfusion injury was demonstrated in a study conducted by Meija-Vilet et al (5). To date, however, no researcher has studied the effects of sprinolactone on hepatic ischamia/reperfusion. We therefore consider that our work will have an important place in the literature by being the first study that investigates this subject.

Under the light of the above mentioned information, this study aimed to investigate the effects of sprinolactone on liver injury resulting from ischemia/reperfusion 
applied at the level of middle and left hepatic artery, portal vein, and bile ducts.

\section{MATERIAL and METHODS}

This experiment was performed after obtaining the approval of the Local Ethics Committee at Marmara University Laboratory Animals Research Center with the protocol code numbered 80.2012.mar, dated 08.11.2012. The rats were obtained from and the experiment was conducted at the same laboratory.

The study used 32 ten-week-old female Norvegian rats of the Wistar albino strain weighing between 200 and 250 grams. The rats were randomly grouped into 4 groups containing 8 rats each and they were kept in wire cages containing 4 rats each under standard laboratory conditions $\left(20-24^{\circ} \mathrm{C}, 50-60 \%\right.$ humidity; 12-hour cycles of light and darkness); the rats were fed ad libitum with standard rat feed and tap water during the whole study period. No enteral or parenteral antibiotics were administered throughout the study.

Each rat was kept in a jar containing ether for 40-60 seconds for anesthesia induction. Following anesthesia induction, ketamin at $100 \mathrm{mg} / \mathrm{kg}$ and chlorpromazine at $1 \mathrm{mg} / \mathrm{kg}$ were administered intraperitoneally (ip) for anesthesia maintenance.

The rats were then laid supine under anesthesia. The anterior abdominal wall was shaved with a scalpel and the shaved area was sterilized with povidone iodine solution. Then, the abdominal cavity was entered via midline incision. Hepatic artery, portal vein, and bile duct were explored and clamped for 45 minutes to create ischemia. At the end of this period, reperfusion was established, and the rats were decapitated 60 minutes later. Spironolactone $(20 \mathrm{mg} / \mathrm{kg}$, p.o) or isotonic saline were applied via oral route for 30 minutes before ischemia. The rats in the control group were applied sham operation and isotonic saline infusion.

1. Sham group: Following the completion of the standard operation, a 2-cc blood sample and a hepatic tissue sample were taken without clamping the hepatic artery, portal vein, and bile ducts.

2. Spironolactone (SPL) group: The rats were orally administered SPL at a dose of $20 \mathrm{mg} / \mathrm{kg}$ for 30 minutes before the time of the sham operation. Then a 2-cc blood sample and a hepatic tissue sample were taken.

3. Ischemia reperfusion (I/R) group: The rats were orally administered isotonic for 30 minutes before the time of the sham operation. Following the completion of the standard operation, hepatic artery, portal vein, and bile ducts were clamped to create ischemia. The rats were subjected to ischemia for only 45 minutes, followed by 60 minutes of reperfusion. At the end of the reperfusion period, a 2-cc blood sample was obtained from the heart and a tissue sample was taken from liver.

4. The Spironolactone administered ischemia/reperfusion (I/R-SPL) group: The rats were orally administered sprinolactone at a dose of $20 \mathrm{mg} / \mathrm{kg}$ for 30 minutes before the time of the hepatic ischemia procedure. The rats were subjected to ischemia for only 45 minutes, followed by 60 minutes of reperfusion. At the end of the reperfusion period a 2-cc blood sample was obtained from the heart and a tissue sample was taken from the liver. The resected hepatic tissues were washed with cold $0.9 \% \mathrm{NaCl}$, wrapped in aluminium foils and stored at $-80^{\circ} \mathrm{C}$ for biochemical studies. After thawing the frozen samples at room temperature, malondialdehyde (MDA), myeloperoxidase (MPO), and glutathione (GSH) levels, Na-K ATPase activity were studied. The samples put into formol were examined for structural damage. The blood samples were centrifuged at 3000 rpm for 15 minutes, and the separated plasma was stored at $-70^{\circ} \mathrm{C}$. The frozen samples were thawed at room temperature for the study of aspartate aminotransferase (AST) and alanine aminotransferase (ALT), tumor necrosis factor-alpha (TNF-a), and interleukin-1 beta (IL-1 $\beta$ ) levels.

\section{Serum Studies}

Determination of serum AST (Biolabo Europe S.A. Catalog No: REF 92025, 02160 Maizy, France) and ALT (Biolabo Europe S.A. Catalog No: REF 80027, 02160 Maizy, France) is a kinetic spectrophotometric method which was perfomed in the Opera Technican Bayer Autoanalyser (Germany) device. TNF-a (BioSource Europe S.A. Catalog No.KRC 3014, Nivelles, Belgium) and IL-1 (ELISA, BioSource Catalog No.KRC0011, Nivelles, Belgium) levels were determined with the ELISA method using specific rat kits.

\section{Tissue Studies}

Determination of free oxygen radicals in tissue was performed by the Chemiluminescence Method $(6,7)$. Tissue samples were put into $2 \mathrm{ml}$ PBS-Hepes buffer, and $4 \mathrm{ml}$ luminol (0.2 mM) and 4 $\mathrm{ml}$ lusigenin (0.2 mM) were added to 2 separate tubes containing samples of the same tissue. Photonic activity occurring as a result of the reaction of reactive oxygen species and luminol and lusigenin were recorded by a luminometer for 10 minutes and the "area under curve" (AUC) formed by the count was calculated.

To determine MDA and GSH levels, samples of the tissue were homogenized with ice-cold $150 \mathrm{mM} \mathrm{KCl}$. As described by Beuge et al. in 1978 (8) for products of lipid peroxidation, MDA levels were assayed by monitoring thiobarbituric acid reactive substance formation. Lipid peroxidation was expressed in terms of MDA equivalents using an extinction coefficient of $1.56 \times 10^{5}$ $\mathrm{M}^{-1} \mathrm{~cm}^{-1}$ and results were expressed as nmol MDA/g tissue. GSH measurements were performed with the modification of the Ellman procedure (9). After centrifugation at $1077 \times \mathrm{g}$ for $10 \mathrm{~min}$, $0.5 \mathrm{~mL}$ of supernatant was added to $2 \mathrm{ml}$ of $0.3 \mathrm{~mol} / \mathrm{L} \mathrm{Na}{ }_{2} \mathrm{H}$ $\mathrm{PO} 4.2 \mathrm{H}_{2} \mathrm{O}$ solution. A $0.2 \mathrm{ml}$ solution of dithiobisnitrobenzoate (0.4 mg/ml 1\% sodium citrate) was added, and the absorbance at $412 \mathrm{~nm}$ was measured immediately after mixing. GSH levels were calculated using an extinction coefficient of $1.36 \times 10^{4} \mathrm{M}^{-1}$ $\mathrm{cm}^{-1}$. Results were expressed in $\mu \mathrm{mol} \mathrm{GSH} / \mathrm{g}$ tissue. 
Tissue MPO was measured with the Hillegeas method (10). Tissue samples taken immediately after decapitation were washed with isotonic saline to remove any blood clots and debris, dried with a filter paper, and weighed. The liver sample was homogenized with $50 \mathrm{mM} \mathrm{K}_{2} \mathrm{HPO}_{4}(\mathrm{pH}: 6)$ to prepare a 10\% homogenate, and it was centrifuged at $41400 \mathrm{~g}$ for 10 minutes at $4^{\circ} \mathrm{C}$. The supernatant was discarded; and the samples that were re-homogenized by adding 0.5\% HETAB (Hexadesyltrimethyl-ammonium bromide) to the precipitate were frozen, thawed, and sonicated for three times. Then the samples were centrifuged at $41400 \mathrm{~g}$ for 10 minutes at $4^{\circ} \mathrm{C}$. The supernatant was discarded and the precipitate was added $50 \mathrm{mM} \mathrm{K}_{2} \mathrm{HPO}_{4}(\mathrm{pH}: 6), 20 \mathrm{mM} \mathrm{H}_{2} \mathrm{O}_{2}$, and o-Dianizidine-2 $\mathrm{HCl}$. It was incubated in a $37^{\circ} \mathrm{C}$ water bath for 3 minutes, and added $2 \%$ sodium azide to stop color reaction. The samples were then centrifuged at $41400 \mathrm{~g}$ for 10 minutes at $4^{\circ} \mathrm{C}$, the supernatant was discarded, and the absorbance level of the final color was read at $460 \mathrm{~nm}$ in spectrophotometry.

Determination of tissue $\mathrm{Na}^{+} / \mathrm{K}^{+}$-ATPase activity was done with the Reading and İsbir method (11). The liver tissue sample was homogenized in a 10\% sucrose solution and centrifuged at 3000 rpm for 10 minutes. Zero point one milliliter of the supernatant was discarded and the homogenates were incubated in a suitable medium containing $3 \mathrm{mM}$ ATP. Mg2 ${ }^{+}$-ATPase activity was determined in the presence of $1 \mathrm{mM}$ ouabain while total ATPase activity was determined in the presence of $100 \mathrm{mM} \mathrm{NaCl}, 5 \mathrm{mM}$ $\mathrm{KCl}, 6 \mathrm{mM} \mathrm{MgCl}$, $0.1 \mathrm{mM}$ EDTA, and $30 \mathrm{mM}$ Tris $\mathrm{HCl}(\mathrm{pH}$ 7.4). The difference between total ATPase activity and $\mathrm{Mg}^{2+}$-ATPase activity was considered $\mathrm{Na}^{+} / \mathrm{K}^{+}$-ATPase activity, and the specific activity of the enzyme was expressed as nmol Pi mg-1 proteinh ${ }^{-1}$. The protein concentration of the supernatant was measured with the Lowry method (12).

\section{The Method of Histopathological Examination}

Light microscope: The tissue samples were put into 10\% formol, washed with tap water for at least 3 hours or overnight, dehydrated with increasing alcohol concentrations (70\% alcohol for 15 minutes, 90\% alcohol for 15 minutes, 96\% alcohol for 30 minutes, 100\% alcohol twice for 30 minutes, 100\% toluen twice for 30 minutes), and waited in paraffin at $60^{\circ} \mathrm{C}$ overnight, and embedded in parafin blocks on the next day. Following the blocking procedure, 5-6 $\mathrm{mm}$ sections were obtained from the samples and put on slides, waited in toluene for 2 hours for dewaxing, subjected to reduction to water (treated with 100\% alcohol for 2 minutes, 90\% alcohol for 2 minutes, $70 \%$ alcohol for 2 minutes), and put in distilled water. Following treatment with hematoxylin for 15 minutes, the samples were put in tap water for empurpling process. After adding eosin and distilled water for 5 minutes, dehydration procedure was repeated with increasing concentrations of alcohol (70\% alcohol for 2 minutes, 90\% alcohol for 2 minutes, 96\% alcohol for 2 minutes, 100\% alcohol for 10 minutes). Then the samples were washed with Toluene twice (first bath for 5 minutes, second bath for 10 minutes), covered with Entellan, and examined under light microscope.

\section{Statistical Analysis}

Serum ALT, AST, TNF- $a$, and IL-1 $\beta$ levels and hepatic GSH, MDA, luminol, lucigenin levels, $\mathrm{Bcl}-2 / \mathrm{Bax}$ ratio, and $\mathrm{MPO}, \mathrm{Na}^{+}, \mathrm{K}^{+}$-ATPase, caspase 3 and caspase 9 activities were compared with one-way analysis of variance (ANOVA) test, with paired comparisons being performed with Tukey's test.

A p value of less than 0.05 was considered statistically significant.

\section{RESULTS}

In our study ALT, AST, TNF- $a$, IL-1 $\beta$ levels in serum, and GSH, MDA, luminol, lucigenin levels, $\mathrm{MPO}, \mathrm{Na}^{+}, \mathrm{K}^{+}$-ATPase activities in liver tissue were compared between the groups with one-way analysis of variance (ANOVA) test, with paired comparisons being performed with Tukey's test.

In the group applied with hepatic IR serum, AST, ALT, TNF-a, and $\mathrm{IL}-1 \beta$ levels were significantly higher than the sham group. On the other hand, these parameters approximated to the control levels with SPL administration (Table 1).

Hepatic GSH level was lower in the IR group than the sham group. This decrease was largely prevented after the SPL administration in the IR group (Figure 1A). MDA levels were significantly higher in the IR group than the sham group. SPL administration significantly blunted this increase in the MDA levels (Figure 1B).

Table 1. Serum aspartate aminotransferase (AST), alanine aminotransferase (ALT), tumor necrosis factor-alpha (TNF-a) and interleukin 1-beta (IL$1 \beta$ ) levels of the study groups in hepatic ischemia/reperfusion (I/R) model in rats.

\begin{tabular}{|c|c|c|c|c|}
\hline & Sham & SPL & I/R & I/R-SPL \\
\hline AST (U/L) & $56.5 \pm 7.5$ & $61.1 \pm 5.5$ & $139.2 \pm 15.1^{* * *}$ & $62.3 \pm 8.8^{+++}$ \\
\hline $\operatorname{ALT}(\mathrm{U} / \mathrm{L})$ & $53.1 \pm 4.9$ & $59.7 \pm 5.6$ & $142.5 \pm 14.8^{* * *}$ & $90.8 \pm 12.6^{+}$ \\
\hline TNF-a (pg/ml) & $51.2 \pm 2.96$ & $44.5 \pm 3.1$ & $78.70 \pm 4.2^{* * *}$ & $51.90 \pm 2.2^{+++}$ \\
\hline $\mathrm{IL}-1 \beta(\mathrm{pg} / \mathrm{ml})$ & $359 \pm 22$ & $319 \pm 16$ & $466 \pm 28^{* *}$ & $371 \pm 11^{+}$ \\
\hline
\end{tabular}




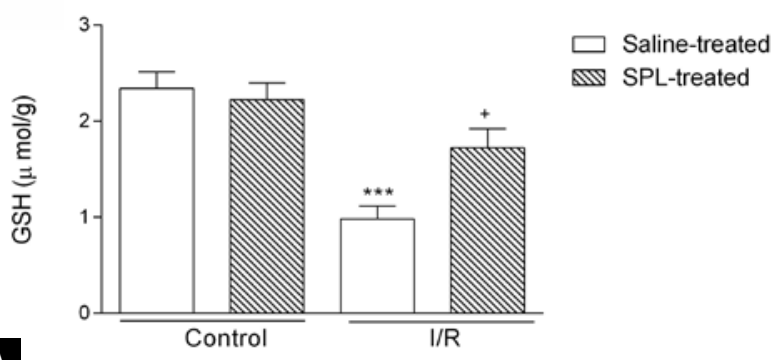

\section{A}

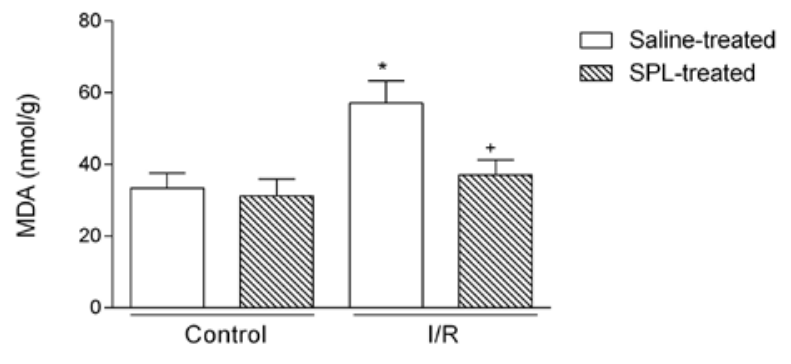

Figure 1. A. Tissue GSH, level of the study groups in the hepatic ischemia/reperfusion model (I/R) in rats. SPL: Spironolactone. ${ }^{* *} \mathrm{p}<0.001 \mathrm{vs}$. sham group, $+p<0.05$ vs. I/R group. B. Tissue MDA, level of the study groups in the hepatic ischemia/reperfusion model (I/R) in rats. SPL: Spironolactone. * $\mathrm{p}<0.05$ vs. sham group, $+\mathrm{p}<0.05$ vs. I/R group.
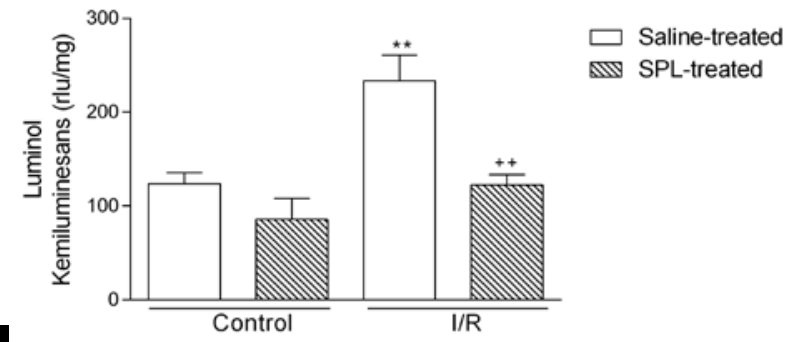

B

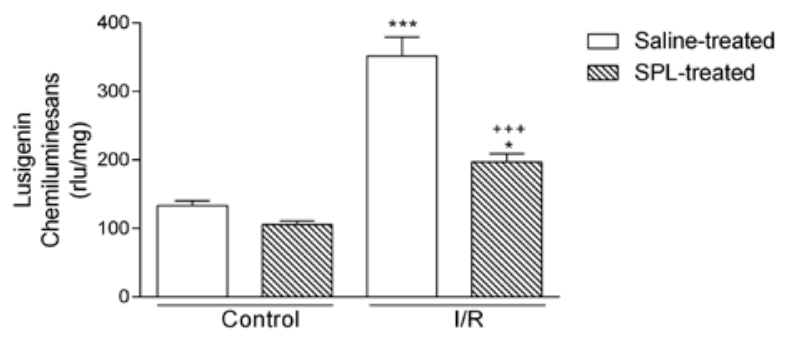

Figure 2. A. Tissue Luminol level of the study groups in the hepatic ischemia/reperfusion model (I/R) in rats. SPL: Spironolactone. ${ }^{* *} \mathrm{p}<0.01 \mathrm{vs}$. sham group; $++p<0.01$ vs. I/R group. B. Tissue Lucigenin level of the study groups in the hepatic ischemia/reperfusion model (I/R) in rats. SPL: Spironolactone. ${ }^{*} p<0.01,{ }^{* * *} p<0.001$ vs. sham group; $+++p<0.001$ vs. I/R group.
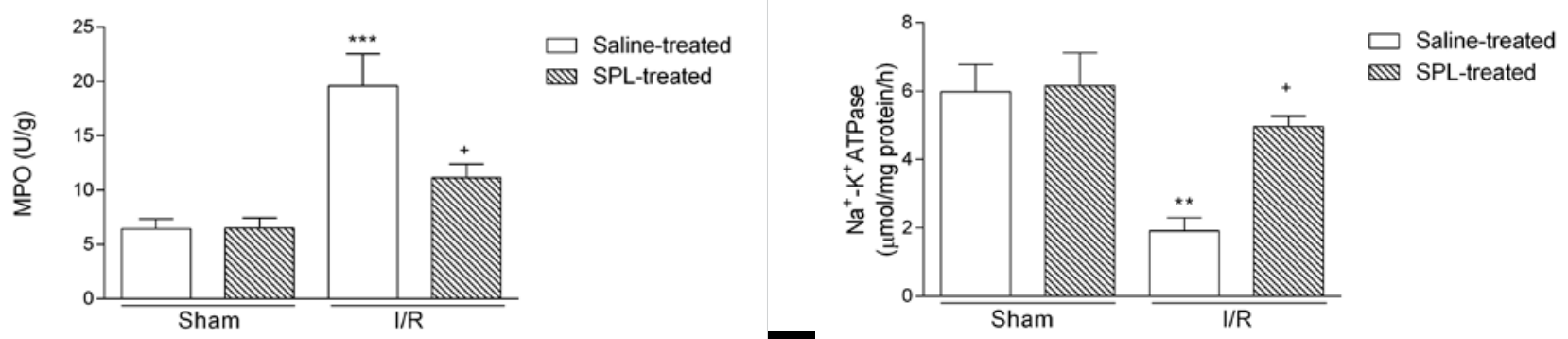

A

B

Figure 3. A. Tissue MPO, levels of the study groups in the hepatic ischemia/reperfusion model (I/R) in rats. SPL: Spironolactone. ${ }^{* *} p<0.001 \mathrm{vs.} \mathrm{sham}$ group; $+\mathrm{p}<0.05$ vs. I/R group. B. Tissue $\mathrm{Na}^{+}-\mathrm{K}^{+}$ATPase levels of the study groups in the hepatic ischemia/reperfusion model (I/R) in rats. SPL: Spironolactone. ${ }^{* *} p<0.01$ vs. sham group; $+p<0.05$ vs. l/R group.

Hepatic luminol and lucigenin levels were significantly higher in the IR group than the sham group. This increase was observed to be significantly inhibited by SPL in the IR group (Figure 2A, B).

While hepatic ischemia led to a significantly increased neutrophil infiltration and thus MPO levels in the hepatic tissue compared to the sham group, MPO activity was significantly reduced in the SPL administered group and approached the MPO levels of the sham group (Figure $3 \mathrm{~A}$ ). $\mathrm{Na}^{+}-\mathrm{K}^{+}$-ATPase activity was lower in the IR group than the sham group. This reduction was largely prevented in the SPL administered group (Figure 3B).

The histopathological examination of the sham group showed that sinusoids and hepatocytes were intact and liver parenchyma preserved its normal morphology (Figure 4A), SPL administered group revealed intact sinusoids and hepatocytes with preserved morphology of the liver parenchyma (Figure 4B), IR group demonstrated extensive congestion and hepatocyte 

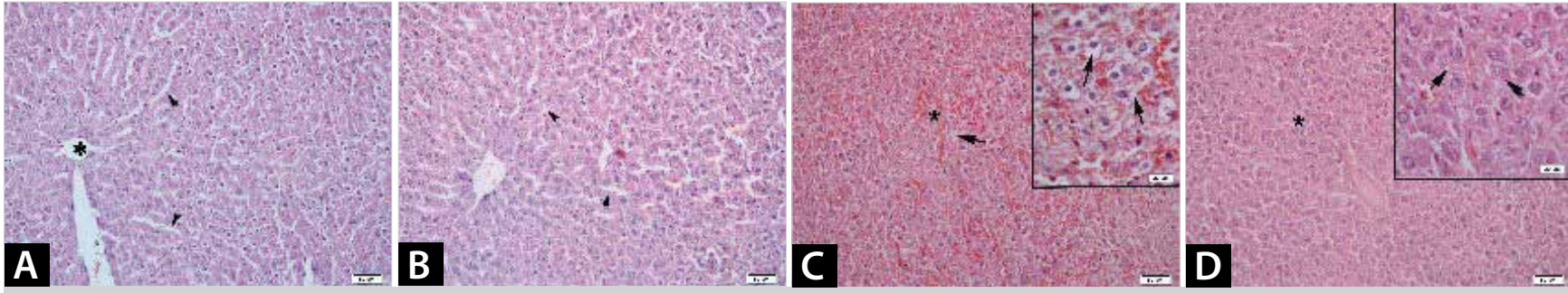

Figure 4. A. Sham group, central vein $\left(^{*}\right)$ and sinusoids $(\bullet)$ with smooth contours, B. SPL group, sinusoids with smooth contours ( $\left.\bullet\right)$. C. Hepatic ischemia group, extensive congestion in sinusoids (arrows) and central vein $\left(^{*}\right)$. D. Hepatic ischemia and SPL group, reduced congestion in sinusoids (arrows) and central vein $\left(^{*}\right)$.

degeneration caused by ischemia (Figure 4C) and SPL administered IR group demonstrated low-intensity sinusoidal and hepatocyte degeneration despite mild congestion (Figure 4D).

\section{DISCUSSION}

Ischemia, defined as oxygen deprivation of any tissue or organ as a result of insufficient perfusion secondary to the cessation of blood flow, and subsequent reperfusion together trigger a series of pathological reactions resulting in cell death and organ dysfunction. During the process of ischemia, cell death ensues as a result of the depletion of cellular energy stores and the accumulation of toxic metabolites. Restoration of blood flow is essential for both cellular regeneration and clearance of toxic metabolites. Nevertheless, a number of studies have indicated that tissue reperfusion paradoxically gives rise to a substantially more severe injury in ischemic tissue compared to that inflicted by ischemia per se (13).

Although dysfunction following reperfusion injury shows variability depending on structural alterations of an organ, oxygen radicals have been determined to be responsible for this injury in every organ (14).

In hepatic tissue, it was first observed in an experimental liver transplantation carried out by Toledo-Pereyra et al. in 1975 (15). It resulted in graft necrosis in the transplanted liver, which culminated into congestion, progressive thrombosis, and organ failure (16). Since blood loss during major liver surgery is closely related to mortality and morbidity, it should be kept at minimum through vascular isolation of the liver. Maneuvers performed to limit afferent blood flow of the liver primarily result in hepatic ischemia. Once the obstacle to hepatic blood flow is removed, the reperfusion process begins. IR injury is the leading cause of post-transplant dysfunction (17).

In an experimental study in rats, we biochemically and immunohistochemically evaluated pathological alterations in the liver tissue secondary to hepatic IR which was formed by clamping the middle and left hepatic arteries, portal vein, and bile duct. We aimed to assess the antioxidant and antiapoptotic actions of SPL, a mineralocorticoid receptor antagonist, in an attempt to investigate its protective effects against IR injury.
Although there exist various different methods to assess liver function after ischemia reperfusion injury, determination of the activities of AST, ALT is currently the most accepted method. The activities of these enzymes are known to increase in hepatic injury (18). Various studies have shown the antioxidant protective effects of mineralocorticoid receptor antagonists $(19,20)$.

In our study, serum AST and ALT levels were significantly higher in the hepatic IR group compared to the control group. In contrast, the levels approached to the control levels upon the administration of SPL. These results suggest that tissue injury was less intense in the SPL administered group.

TNF-a is a cytokine released from monocytes, macrophages, and $T$ cells that are abundant in the peritoneum and splanchnic tissues. It is also found in Kuppfer cells, the largest macrophage aggregate in the human body. TNF-a has some significant roles in muscle catabolism during stress and cachexia (1). In an experimental renal IR model, Kabasakal et al. have shown that IR injury can be reduced by inhibiting the formation of TNF-a (21). The result that we found is parallel to the literature. We found significantly higher TNF-a levels in the hepatic IR group when compared with the control group. In contrast, the SPL administered IR group showed a significantly blunted increase in TNF-a level, which approached that of the control group.

IL-1 is released from KCs in response to inflammatory stimuli. It is also synthesized by neutrophils, epithelial cells, and endothelial cells. Kato et al. have reported that IL-1 $\beta$ level is one of the major indicators of hepatic IR injury (22). In our study, the hepatic IR group had significantly higher serum IL-1 $\beta$ levels than the control group. On the other hand, SPL administered group enjoyed a significantly reduced increase, and IL-1 $\beta$ levels approached the control levels. Mineralocorticoid receptor antagonist Spironolactone has been shown to inhibit proinflammatory cytokines in previously conducted inflammation studies $(23,24)$. The results that we found in our study are parallel to the literature. Because of the hepatic ischemia/reperfusion, increased values were near to normal values with spironolactone application.

Lipids are among the main targets of free radicals that are formed during ischemia reperfusion. Lipid peroxidation is considered by some researchers a key factor in IR injury (25). 
Reactive oxygen species take one hydrogen atom from polyunsaturates fatty acids and initiates lipid peroxidation to form hydroperoxides. These reactions cause cell membrane to lose its liquidity and integrity, which ultimately leads to the release of cellular fractions to the surrounding medium, and cell death. These subcellular structures trigger inflammatory events and further aggravate injury (26). Different methods are used to detect tissue lipid peroxidation. One of the most widely used among them is the determination of the levels of MDA, a conjugated diene. Our study showed that MDA levels were significantly higher in the liver IR group compared to the controls. SPL administration substantially reduced the increase in MDA level.

All aerobic living beings are subjected to oxidative stress during cellular metabolism. Free radicals such as $\mathrm{H}_{2} \mathrm{O}_{2}, \mathrm{O}_{2}$, which are formed in an organism, are transformed into more toxic metabolites and attack various targets including DNA, lipids, and proteins, disrupting metabolic processes. However, organisms possess many defensive mechanisms to neutralize these reactive agents. Referred to as the "antioxidant defense system", this system has glutathion as the most important component. GSH reacts with free radicals and peroxides to protect cells against oxidative injury. GSH concentration has been shown to be reduced rapidly during hepatic IR injury as a result of being used to neutralize reactive oxygen molecules. Many studies have shown that exogenously administered GSH increases intracellular GSH levels and prevents oxidative injury. Therefore, GSH has a major protective effect against oxidative injuries (27). Our study indicated lower hepatic GSH levels in the IR group than the sham group. This reduction in GSH levels was prevented by SPL in the IR group.

Studies have shown that agents used as antioxidants prevent the increase in MDA levels by increasing GSH levels $(28,29)$. In this study, Spironolactone, which we used as a protective agent, increased the levels of decreased glutathione in the liver and significantly decreased the levels of MDA.

Neutrophils activated by ischemia reperfusion release myeloperoxidase into the medium and induce the formation of hypochloric acid ( $\mathrm{HOCl}$ ) from $\mathrm{H}_{2} \mathrm{O}_{2}$ and chloride ions. $\mathrm{HOCl}$ exerts cytotoxic effects by oxidizing sulphides, inactivating cytochrome and heme proteins, and degrading amino acids and proteins (30). Tissue MPO activity is considered an indicator of neutrophil accumulation. Our study demonstrated that while the induction of hepatic ischemia caused neutrophil infiltration and an associated significant increase in MPO activity compared to the control group, MPO activity was significantly lowered in the SPL administered group, approaching to that in the sham group. Considering the positive effects of Spironolactone on blood parameters used in our study, the fact that these agents significantly suppressed myeloperoxidase enzyme in the tissues supports that this enzyme plays an important role in $\mathrm{HI}$. Thus, the presence of inhibitor properties on the MPO activity of the agents used in HI therapy will ensure that the tissue is protected against oxidation and will increase the success of treatment. Spironolactone has been reported to reduce increased myeloperoxidase activity during inflammatory events by the effect of free radical scavenging (31). When all these studies are taken into consideration, it is understood that our findings are in conformity with the literature.

$\mathrm{Na}^{+}-\mathrm{K}^{+}$-ATPase is an important membrane enzyme playing a key role in hepatocyte structure and physiology by maintaining sodium-potassium gradient on cellular membrane. It is an important indicator of maintenance of tissue viability and liver function. Studies have shown a reduction in $\mathrm{Na}^{+}-\mathrm{K}^{+}$-ATPase level after hepatic ischemia reperfusion $(32,33)$. Our study revealed that $\mathrm{Na}^{+}-$ $\mathrm{K}^{+}$-ATPase activity in the liver tissue was lower in the IR group when compared to the control group. This reduction was largely prevented by treatment with SPL.

Luminol hydroxyl radical is an indicator of the formation of reactive oxygen metabolites such as hydrogen peroxide and hypochloric acid. Lusigenin marks the formation of superoxide anion radical (33). They indirectly indicate the level of ROM-mediated tissue injury. In our study, luminol levels were higher in the IR group than the control group, and the increase was prevented by SPL administration. Lucigenin levels were significantly higher in the hepatic IR group compared to the controls. SPL administration, however, reduced this elevation to a significant extent. Spironolactone suggests that this effect is probably accomplished by inhibiting neutrophil infiltration.

Hepatic IR injury is known to induce hepatocellular necrosis and sinusoidal congestion. In our study, the histopathological examination of the control and SPL groups revealed that sinusoids and hepatocytes were intact, and liver parenchyma preserved its normal morphology; the histopathological examination of the IR group showed that hepatic ischemia caused extensive congestion and hepatocyte degeneration; and the histopathological examination of the IR group treated with SPL indicated low-grade sinusoidal and hepatocellular degeneration despite mild congestion.

In conclusion, it was observed that GSH level and $\mathrm{Na}^{+}-\mathrm{K}^{+}$-ATPase activity intensity decreased, lumiol, lucigenin, MDA level and MPO activity increased, and accordingly, hepatic dysfunction occurred in the liver after IR of the hepatic tissue. SPL provided protection against IR by largely reducing IR-induced injury. These results suggest that SPL treatment can lower the morbidity and mortality of hepatic IR to a considerable extent by preventing IR-induced free radical-mediated organ injury and dysfunction.

Ethics Committee Approval: This experiment was performed after obtaining the approval of the Local Ethics Committee at Marmara University Laboratory Animals Research Center with the protocol code numbered 80.2012.mar, dated 08.11.2012. 
Informed Consent: Written informed consent was obtained from patients who participated in this study.

Peer-review: Externally peer-reviewed.

Author Contributions: Concept - S.A., B.S., A.Ö.Ş.; Design - S.A., A.Ö.Ş.; Supervision - S.A., A.Ö.Ş.; Resource - S.A., A.A., A.V.Ö., S.Ç., N.M., C.E.; Materials - S.A., B.S., A.Ö.Ş.; Data Collection and/or Processing - S.A., B.S., A.Ö.Ş.; Analysis and/or Interpretation - S.A., A.Ö.Ş.; Literature Search - S.A., B.S., A.Ö.Ş.; Writing Manuscript - All of authors; Critical Reviews - S.A., A.Ö.Ş.

Conflict of Interest: The authors have no conflicts of interest to declare.

Financial Disclosure: The authors declared that this study has received no financial support.

\section{REFERENCES}

1. Şehirli Ö, Özel Y, Dulundu E, Topaloğlu Ü, Ercan EŞ̧ener G. Grape seed extract treatment reduces hepatic ischemia-reperfusion injury in rats. Phytotherapy Research 2008;22:43-8. [CrossRef]"

2. AktaşS, Sevmiş Ş, Şeker M, Korkut E, Karakayalı H. Analysis of risk factors affecting coagulopathy after donor hepatectomy in a newly established liver transplant center. Turk J Surg 2017;33:69-75. [CrossRef].

3. Tavusbay C, Kamer E, Acar T, Kokulu I, Kar H, Gür Ö. Portal vein thrombosis as a rare cause of abdominal pain: when to consider? Turk J Surg 2015;33:126-9. [CrossRef]"

4. Carden DL, Granger DN. Phatophsiology of ischemia-reperfusion injury. J Pathol 2000;190:255-66:[CrossRef]

5. Mejia-Vilet JM, Ramirez V, Cruz C, Uribe N, Gamba G, Bobadilla NA. Renal ischemia-reperfusion injury is prevented by the mineralocorticoid receptor blocker spironolactone. Am J Physiol Renal Physiol 2007;293:F78-F86.[CrossRef].

6. Davies GR, Simmonds NJ, Stevens TRJ, Grandison A, Blake DR, Rampton $D S$. Mucosal reactive oxygen metabolite production in duodenal ulcer disease. Gut 1992;33:1467-72:[CrossRef],

7. Haklar G, Yüksel M, Yalçın AS. Chemiluminescence in the measurement of free radicals: theory and application on a tissue injury model. Marmara Med J 1988;11:56-60.

8. Beuge JA, Aust SD. Microsomal lipid peroxidation. Methods Enzymol 1978,53:302-11.[CrossRef],

9. Beutler E. Glutathione in Red Blood Cell Metabolism. A Manual of Biochemical Methods. New York: Grune\&Stratton, 1975:112-4.

10. Hillegass LM, Griswold DE, Brickson B, Albrightson-Winslow C. Assessment of myeloperoxidase activity in whole rat kidney. J Pharmacol Meth 1990;24:285-95. [CrossRef]

11. Reading HW, Isbir T. The role of cation activated ATPase in transmitter release from the rat iris. Q J Exp Physiol 1980;65:105-16. [CrossRef].

12. Lowry OH, Rosenbrough NJ, Farr AL, Randall RJ. Protein measurements with the folin phenol reagent. J Biol Chem 1951;193:265-75.

13. Zimmerman BJ,_Granger DN. Reperfusion injury. Surg Clin North Am 1992;72:65-83:"CrossRef]"

14. Wilhelm J. Metabolic aspects of membrane lipid peroxidation. Acta Univ Carol Med Monogr 1990;137:1-53.

15. Toledo-Pereyra LH, Simmons RL, Najarian JS. Protection of the ischemic liver by donor pretreatment before transplantation. Am J Surg 1975;129:513-7] [CrossRef]

16. Yoshikawa T, Murakami M, Yoshida N, Seto O, Kondo M. Effect of superoxid dismutase and catalase on diseminated intravascular coagulation in rats. Thrombosis and Haemostasis 1993;50:869-72: [CrossRef]"
17. Crenesse D, Laurens M, Heurteaux C, Cursio R, Saint-Paul MC, SchmidAlliana $A$, et al. Rat liver ischemia reperfusion induced apoptosis and necrosis are decreased by FK506 pretreatment. Eur J Pharmacol 2003;473:177-84. [CrossRef].

18. Yabe Y, Kobayashi N, Nishihashi T, Takahashi R, Nishikawa M, Takakura $Y$, et al. Prevention of neutrofil-mediated hepatic ischemia reperfusion injury by superoxide dismutase and catalase derivatives. J Pharmacol Exp Ther 2001;298:894-9.

19. Taye A, Abdel-Raheem IT. Hepatoprotective effect of the selective mineralocorticoid receptor antagonist, eplerenone against carbon tetrachloride-induced liver injury in rats. Ann Hepatol 2012;11:384-91. [CrossRef]

20. Silvestre JS, Robert V, Escoubet B, Heymes C, Oubénaïssa A, Desopper C, et al. Different regulation of cardiac and renal corticosteroid receptors in aldosterone-salt treated rats: effect of hypertension and glucocorticoids. J Mol Cell Cardiol 2000;32:1249-63" [CrossRef]"

21. Şehirli AÖ, Koyun D, Tetik Ş, Özsava D, Yiğiner Ö, Çetinel Ş, et al. Me latonin protects against ischemic heart failure in rats. J Pineal Res 2013;55:138-48. [CrossRef]

22. Kato A, Gabay C, Okaya T, Lentsch AB. Specific role of interleukin-1 in hepatic neutrophil recruitment after ischemia/reperfusion. Am J Pathol 2002;161:1797-803"[CrossRef]"

23. Denollet J, Schiffer AA, Kwaijtaal M, Hooijkaas H, Hendriks EH, Widdershoven JW, et al. Usefulness of type D personality and kidney dysfunction as predictors of interpatient variability in inflammatory activation in chronic heart failure. Am J Cardiol 2009; 103:399-404 [CrossReff],

24. Mikkelsen M, Sonder SU, Nersting J, Bendtzen K. Spironolactone induces apoptosis in human mononuclear cells. Association between apoptosis and cytokine suppression. Apoptosis 2006;11:573-9. [CrossRef]

25. Tappel AL. Lipid peroxidation damage to cell components. Fed Proc 1973;32:1870-4

26. Jaeschke H, Smith CW, Clemens MG, Ganey PA, Roth RA. Mechanism of inflammatory liver injury: adhesion molecules and cytotoxicity of neutrophils. Toxicol Appl Pharmacol 1996;139:213-26:[CrossRef]

27. Mandel GL. ARDS, neutrophils and pentoxifylline. Am Rev Respir Dis 1998;138:1103-5.[CrossRef],

28. Erkanli K, Kayalar N, Erkanli G, Ercan F, Sener G, Kirali K. Melatonin protects against ischemialreperfusion injury in skeletal muscle. J Pineal Res 2005;39:238-42. [CrossRef].

29. Meister A Anderson ME. Glutathione. Ann Rev Biochem 1983;52:711. [CrossRef]"

30. Carden DL, Granger DN. Phatophsiology of ischemia-reperfusion injury. J Pathol 2000;190:255-66, [CrossReff],

31. Sehirli AO, Cetinel S, Ozkan N, Selman S, Tetik S, Yuksel M, Dulger FG. St. John's wort may ameliorate 2,4,6-trinitrobenzenesulfonic acid colitis off rats through the induction of pregnane $X$ receptors and/or P-glycoproteins. J Physiol Pharmacol 2015;66:203-14.

32. Benkoel L, Dodero F, Hardwigsen J, Mas E, Benoliel AM, Botta-Fridlund $D$, et al. Effect of ischemia-reperfusion on $\mathrm{Na}+, \mathrm{K}+-$-ATPase expression in human liver tissue allograft: image analysis by confocal laser scanning microscopy. Dig Dis Sci 2004;49(9):1387-93. [CrossRef]"

33. Atalay S, Soylu B, Aykaç A, Velioğlu-Öğünç A, Çetinel Ş, Özkan N, et al. Protective effects of St. John's wort in the hepatic ischemia/ reperfusion injury in rats. Turk J Surgery 2018;34:198-204, [CrossRef]'

34. Okuda M, Lee HC, Kumar C, Chance B. Oxygen radical generation during ischemia-reperfusion in the isolated perfused rat liver monitored by enhanced chemiluminescence. Circ Shock 1992;38(4):228-37. 


\section{ORIJINAL ÇALIŞMA-ÖZET}

Turk J Surg 2019; 35 (4): 285-292

\section{Sıçanlarda hepatik iskemi/reperfüzyon hasarına karşı spironolaktonun koruyucu etkisi}

Süleyman Atalay ${ }^{1}$, Belkıs Soylu ${ }^{2}$, Aslı Aykaç ${ }^{3}$, Ayliz Velioğlu Öğünç ${ }^{4}$, Şule Çetinel ${ }^{5}$, Naziye Özkan ${ }^{5}$, Can Erzik ${ }^{6}$, Ahmet Özer Şehirli ${ }^{7}$

${ }^{1}$ Haydarpaşa Numune Eğitim ve Araştırma Hastanesi, Genel Cerrahi Kliniği, İstanbul, Türkiye

${ }^{2}$ Marmara Üniversitesi Eczaclık Fakültesi, Farmakoloji Anabilim Dalı, İstanbul, Türkiye

${ }^{3}$ Yakın Doğu Üniversitesi Tıp Fakültesi, Biyofizik Anabilim Dalı, Lefkoşa, Kuzey Kıbrıs Türk Cumhuriyeti

${ }^{4}$ Marmara Üniversitesi Sağlık Hizmetleri Meslek Yüksek Okulu, Biyokimya Anabilim Dalı, İstanbul, Türkiye

${ }^{5}$ Marmara Üniversitesi Tıp Fakültesi, Histoloji ve Embriyoloji Bilim Dalı, İstanbul, Türkiye

${ }^{6}$ Marmara Üniversitesi Tıp Fakültesi, Tıbbi Biyoloji Anabilim Dalı, İstanbul, Türkiye

${ }^{7}$ Yakın Doğu Üniversitesi Diş Hekimliği Fakültesi, Farmakoloji Anabilim Dalı, Lefkoşa, Kuzey Kıbrıs Türk Cumhuriyeti

\section{ÖZET}

Giriş ve Amaç: Bu çalışmada, hepatik iskemi reperfüzyon hasarında olası koruyucu etkilerini saptamak için spironolaktonun (SPL) antioksidan etkilerinin araştırılması amaçlanmıştır.

Gereç ve Yöntem: Wistar albino sıçanların hepatik arter, portal ven ve safra kanalı, bir iskemi dönemi oluşturmak için anestezi altında 45 dakika boyunca klemplendi. 60 dakikalık reperfüzyonun sonunda sıçanlar dekapite edilmiştir. SPL ( $20 \mathrm{mg} / \mathrm{kg}$, p.o.) veya SF, iskemiden 30 dakika boyunca oral yolla uygulandı. Kontrol grubundaki sıçanlara sham cerrahisi yapıldı ve izotonik salin verildi. Serumda aspartat aminotransferaz (AST), alanin aminotransferaz (ALT), tümör nekrozis faktör-alfa (TNF-a) ve interlökin-1 beta (IL-1 $\beta$ ) düzeyleri ölçüldü. Malondialdehid, glutatyon, luminol ve lucigenin seviyeleri, miyeloperoksidaz ve $\mathrm{Na}^{+}-\mathrm{K}^{+}$-ATPase enzim aktiviteleri ve ışı mikroskobu altında doku hasarını incelemek üzere analiz edilmiştir

Bulgular: IR; $A S T$, ALT, TNF-a ve IL-1 $\beta$ seviyelerini ve MDA, luminol ve lusigenin seviyelerini ve MPO aktivitelerini artırırken, GSH düzeylerinde, $\mathrm{Na}^{+} \mathrm{K}^{+}$-ATPase aktivitesinde azalmaya neden olmuştur. Spironolakton uygulaması bu değerleri önemli ölçüde iyileştirmiştir.

Sonuç: SPL'nin iskemi/reperfüzyon hasarına karşı çeşitli mekanizmalarla koruyucu etkileri, bu ajanın klinik uygulamada yeni bir tedavi ajanı olabileceğini düşündürmektedir.

Anahtar Kelimeler: Hepatik iskemi reperfüzyon, spironolakton, malondialdehit, glutatyon, sitokinler

Doi: $10.5578 /$ turkjsurg. 4340 